\title{
Promotion of the Cognition of Child Abuse by Media Information in Mainland China
}

\author{
Tian Tian \\ Postgraduate, Department of Social Policy and Social Work \\ University of York, Heslington, York YO10 5DD, UK \\ *txbctgu@hotmail.com; Mobile: 13972603385 (in China)
}

\section{Keywords: Media Information; Cognition; Child Abuse; Child Protection}

\begin{abstract}
During past several thousand of years, the term 'child abuse' was not popular in China. Most parents was not familiar with the term child abuse and there is no legal definition on it. They did not even agree that child abuse exists in China. Beating or scolding one's child is only known as a kind of strict parenting way. The main reason to have this cognition is of course the traditional Chinese culture. And this unclear cognition of child abuse has impeded the development of child protection and child right work in Mainland China. However, it is information technology that has changed or improved Chinese parents' cognition on child abuse in recent years. The significant way is media report or heated discussion on the internet. This research collected recent five years data about child abuse reported by media and analyzed the data. The result is that the media have made an important contribution to the construction of the cognition on child abuse and the information technology benefits the promotion to protect child and child's rights in Mainland China.
\end{abstract}

\section{Introduction}

In China, traditional culture has been influencing family construction and the way of parenting. Many old sayings in China inherited from generation to generation, such as "No wrong parents in the world", "it is domestic business to discipline or to beat one's own children and others have no right to interfere". In reality, most parents used this way to raise their sons and daughters. They believed that beating or scolding their children was their right and would benefit their children, which seems a fixed discipline. Tiger Mother Amy Chua, a Chinese American professor at Yale University, believes that "This was supposed to be a story of how Chinese parents are better at raising kids than Western ones." [1] Qiao Dongping, a famous scholar on child abuse in China, puts these ideas into "patriarchal system" "which represents the rights of the parents. Patriarchy refers to the controller of a family and the master of the fate of their children." [2] However, The construction of images of the abusers has changed a lot with the development of society, first about the abused child's parents. They have changed gradually from positive images of authority figures, into the negative images of abusers. This kind of image construction can be divided into different levels or categories.

\section{Chinese Changes of Cognition about Child Abuse in Recent Years}

In recent years, the term of child abuse has been accepted gradually by Chinese people in Mainland China. This should owe to media, especially net, which has exposed the cases of child abuse in different images and changed the cognition of public views. From the level of the relationship between parents and children, the construction of images has formed from the non-biological parents to biological parents. A few years ago, the media reported more child abuse problems, mostly caused by step-parents or adoptive parents. But today, it seems that biological parents become the main group of child abuse. Please see the following titles of reports, then you can clearly understand the ugly images of child abuse by biological parents.

JIE Mingyue reported that "A mother who was born after 1990s in Wuhan upload photos to the internet which showed her abusing her own daughter: 'My husband hit me and I would hit my 
child'." [3] In the photos, her hands grabbed her daughter's neck with the fruit knife on her daughter's belly. This young mother's photos of the acts of abuse to her one-year-old daughter released in the QQ space have caught the attention of tens of thousands of netizens.

Another piece of news reported by Sinanet News: "A three-year-old boy in Shenzhen was cruelly beaten only because he was not good at eating." [4] The baby named Little Le was pushed to the ground by his mother, Ms Huang. His head was seriously injured and his life was in critical danger.

Not only the child abuse done by the biological mothers have been reported, but also a biological father has been reported for his abuse to his daughter. "A girl in Hangzhou was abused cruelly by her father and was forced to eat books and drink toilet water." [5] A 13-year-old girl named Xiao $\mathrm{Yu}$ reported to the media for help and accused her biological father for his abusing her and forcing her to eat books and drink toilet water.

These reports constructed the same images of child abuse different from traditional views. These biological parents become main group of perpetrators of child abuse. This kind of media construction brings the term of child abuse to Chinese people.

The image construction of child abuse by parents is also reflected in parents' family or

Economic background and their degree of education. The group is gradually "upgrading" from the poor or less-educated families, to the higher-educated group. At the very beginning, media reported the cases of child abuse which always took place in poor families, in rural areas, where there was history of drug use, or divorce in the family. Now, the media have begun to report some better educated families. For example, Nanjing Case of Child Abuse in 2015 is a typical one which took place in a better educated family [6]. The beaten child's adoptive parents are a journalist and lawyer respectively. The reports in different media add new hot topics. "Gaozhi" (senior intellectuals) becomes another hot word of Nanjing Case of Child Abuse. This case causes new concern about child abuse in the group of senior intellectuals. Two reasons attract public attention.

On the one hand, the boy's parents present a sharp contrast between identity and its behavior. Especially the mother, Ms Li is the head of a famous media outlet with the image labeled with civilization and nobility, but she has used a violent parenting style, seen as inappropriate in modern society. This garnished extremely strong interest from society and ridicule among net friends.

On the other hand, the journalist and lawyer in the network transmission, the same as the specific meaning of the words as "guan er dai" and "fu er dai" (mockingly called the rich second generation" and "the second generation officer "), belong to a professional group with a certain social position. Once they appear as a negative image in the network, they are more likely to draw public attention than ordinary people and more likely to become an object to be mocked and scorned, and are more able to become a channel for aggressive emotional venting about the issues of child abuse. Thus, the parents using the so-called "harsh parenting way" are often constructed with negative images of "toxic parents" by the media. This case adds the cognition of child abuse in Mainland China.

\section{Teachers’ Image of the Collapse: from "Sages" to "Devils"}

The construction of another group of abusers is that of elementary school teachers and kindergarten teachers. Teachers in ordinary peoples' minds in China are sages, and are often called hard-working gardener, the engineer of the human soul and the lighthouse for students. These flashy labels for teachers have made people fear and respect them. Before 1950s, the teachers in sī shú (old-style private school in China) were very strict on students. They enacted severe penalties so that corporal punishment was very popular. Teachers often seized students by their face and ears. A ruler was always put on the teaching desk to be used to beat the student's palm. At that time, however, almost all people, including parents, believed that it was right for a teacher to beat his students because it was good for the children. Parents were always certain that it was the children who were not obedient in class so that they should be punished. This is the traditional educational ideas inherited from thousands of years of history. Now, these ideas still exist in Mainland China. But in recent years, after the media exposed the kindergarten teachers' behavior in beating and scolding children, 
child abuse has been paid wider attention, and the image of teachers as sages has been somewhat reconstructed. The images of some teachers are now presented as codes of "devil" and ugliness. The exposure of child abuse in Wenling Kindergarten, where the torturous acts of preschool teachers, raised serious concerns about their professional ethics and those teachers' moral bottom line.

Sinanet reported "Abused Child by Preschool Teacher in Zhejiang is Troubled by Nightmares Whose Impact Might be Lifelong ". [7] In this article with pictures, the exposed preschool teacher is YanYanhong. In her QQ space, there are 702 photos, of which a lot of photos are about her acts of child abuse. One photo is that she sealed a child's mouth with a wide tape on which huo gai (deserve) was written.

Another photo depicts a child who was thrown into a rubbish bin labeled "I have thrown him in." Until the exposure of these photos, the parents believed poor academic performance was the reason for their child being punished at that time. In fact, it was two years after the time when the boy was thrown into rubbish, before the exposure of these photos. Before that, the parents always believed that their child's unwillingness to go to the kindergarten was because of their own mistakes, and few parents thought of teachers to blame. But with the exposure of the photos, parents, public and the department in charge began to pay attention to the problem of kindergarten teachers' management and supervision.

Later, the media also reported a series of preschool teachers' improper behaviors, such as hitting children, putting children in dark room, limiting child's dinner, and needling.

Furthermore, a video showed that a preschool teacher instigated a group of children to beat each other and she stood aside to watch excitedly. Convenient network transmission has completely subverted the traditional image of teachers as sages, and now teachers have shifted into "the devil" in public minds.

Due to the development of today's media, especially the convenience of Internet and television coverage, the awareness of child abuse and child protection has greatly improved in Mainland China. Once cases of child abuse appear in the network media, lots of attention and immediate discussion or different comments will come overwhelmingly. Therefore, the construction of child's image and the image of the abuser are constantly changing with the development of media. Discussed in a different media report, the awareness of child abuse will be gradually be improved and the construction of the concept of child abuse will become clearer and clearer. All of these benefit undoubtedly in contrast to contemporary media.

Media Construction of the Concept of Child Abuse

News analysis shows that the conflict over the child abuse concept mainly arises from the debate between old and new ideas in child education. According to some news reports, parents' traditional education paradigms are being challenged by the changing times, the laws, and also child's growing self-protection awareness. In traditional education paradigms, parents believe their children are their private property and they are entitled to handle their children at their own will. In a Wenzhou child abuse (by father) case reported by Sina on September 24, 2015, for example, the four-year-old daughter was heavily scalded by his father with a heated steel spoon. In response to the police's questioning, the father aged about 30 didn't show much concern. He admitted his behavior, claimed that he just wanted to teach his own kid a lesson, and complained about neighbors reporting to the police. In this case, the father regarded the child as his own private property, typically. News reports showed strong disapproval of such a scenario. Another type of opinion frequently reported take the tone: "I beat the child for his/her own good sake", "Hitting and scolding are the way I love my child", and "Spare the rod, spoil the child", just as believed by the Wolf Dad and the foster mother in the Nanjing child abuse case. Reports said that such opinions are in fundamental conflict with the modern concept of human rights. The media all expressed disapproval of these traditional education paradigms and classified them into the scope of child abuse. The gradual construction of cognition about child abuse has formed under the help of media mainly from the following ways.

One is to bring about public sympathy for abused children. According to a comprehensive report by Xinhua on December 18, in 2013, a series of child injury and abuse cases were exposed to the public, and the crimes were committed in the most terrible ways such as beating and scolding, hand 
cutting, eye digging, burning, sexual abuse, etc., which strained the public's nerves. Below are some headlines on child abuse, which can fully reflect the media hype over child abuse cases. Xinhuanet: "Daughter abused by birth father for five years: head scalded with hot water, mouth seamed with fishing thread" [8], "Six-year-old girl is suspected to be abused to death" [9] and "Dying five-year daughter abused by her mother" [10]; Sina News: "Mother abused 12-year-old daughter to death because she believed the daughter would bring her bad fortune" [11], "Mother kicked, hit and slapped 4-year-old daughter heavily because the girl got some poop on herself by accident" [12], and Sina Video: "A teacher of a school in Nanchong abused deaf-and-mute children" [13]. These headlines emphasizing brutal and harmful acts increased social and public sympathy with child abuse victims, as well as increasingly hatred for the perpetrators. It also triggered public heated discussion to urge the government to take measures to improve child protection policies. In a large number of child abuse reports, emotional descriptions, photos of child victims, and mass publicity over violent acts, were used by the media to trigger the public's anger and condemnation towards abuse behaviors.

The photos, videos and written reports online caused a shock to society, aroused citizens' moral conscience and kindness, attracted much attention from the community, public and government, drove the development of child protection policies in China, and accelerated the establishment of child protection authorities at local levels.

The other is the media's zero tolerance of physical child abuse. The reports and comments on child abuse cases by the two media in the past five years demonstrated a transition from sympathy with parents to sympathy with children, from within understanding to beyond understanding, from assisting in education to resorting to law, and from persuasion and condemnation to zero tolerance. Today's media showed strong disapproval of physical punishment of children, raising it into the scope of child abuse, advocated severe punishment for perpetrators, and called for legal sanctions.

According to a Sina review on April 16, 2015, the case of two girls starved to death in 2013 aroused much attention from society, while the case of a boy being beaten heavily in 2015 once again indicated the need for improved protection of minors. If a child is injured as a result of domestic violence, the perpetrator should be held criminally responsible. From this, we can see that, although the media calls for zero tolerance, physical punishment and violence are still accepted by many people in reality. Therefore, the legal construction to protect child is very important in Mainland China.

\section{The Development of Child Protection Policies and Regulations}

The media's heated discussion and continuous call for child protection have no doubt promoted the development of relevant policies and regulations in mainland China. One example is that guardianship deprivation evolves from a "zombie" law to a new judicial regulation. In reports of child abuse in China, widespread public condemnation and appeals have accelerated the Chinese government's efforts to introduce new regulations on child guardianship deprivation and transfer.

According to Article 53 of the newly revised Law on the Protection of Minors in 2006, where a parent or other guardian does not perform his/her guardianship duties or injures the lawful rights and interests of the minor under his/her guardianship, and fails to make a correction after being educated, the people's court may, upon application of the relevant person or entity, disqualify $\mathrm{him} /$ her from the guardianship, and designate another guardian according to law. The parents who have been disqualified from guardianship shall continue bearing the fosterage expenses according to law.

On November 16, 2012, five street children died from carbon monoxide poisoning after

starting charcoal fire inside a dustbin in Bijie, Guizhou. In May 2013, a child abuse case took place in Jinsha, Guizhou. In April 2013, girls were starved to death by their mother with drug problems. The successive child abuse reports have aroused much attention from the society. Not only the public, but also a large number of professionals, lawyers and sociologists voiced their opinions and called for the government to introduce policies and rules regarding custodianship deprivation through the media. Finally, the Opinions on Legally Handling Several Issues on 
Guardian's Infringement upon the Rights and Interests of Minors were released on December 23, 2014 and became effective on January 1, 2015. Although only three cases of custodianship deprivation were reported from 2015 to date, in terms of child protection, it's a big step forward in the judicial aspect.

The introduction of relevant legal provisions on child protection allows the national public power to replace the parental power that neglects or harms children to some extent to protect children.

In recent years, the Chinese government has been advocating and encouraging the development of social organizations in the policy making. This shows that the media reports on child protection policies play a bridging role between the public and the government: on one hand, the media help facilitate the release and implementation of national policies by providing coverage and explanation; while on the other hand, the media trigger the public's concerns by reporting extreme cases to promote the introduction of child protection policies in the country.

\section{Conclusion}

It is media information that has made great contribution to the promotion of the cognition on child abuse in Mainland China. Media have changed Chinese parents' traditional ideas inherited from several thousands of years about how to nurture their children. The open data show us that biological parents may become perpetrators of child abuse. Traditional teachers' image of sages has collapsed by the data provided by media. So the image construction of parents and teachers experienced a shift from a positive image to a negative image of child-abusing perpetrators. The heated discussions on web about some cases to beat or scold children have brought the term child abuse into Chinese parents' cognition. Government personnel voices were most frequently heard in media reports, followed by family member's voices. The media reports on child protection policies play a bridging role between the public and the government: on one hand, the media help facilitate the release and implementation of national policies by providing coverage and explanation; on the other hand, the media trigger the public's concerns by reporting extreme cases to promote the introduction of child protection policies in the country. Affected by government policies, the media's construction of child abuse tends to focus on harm to children in cases, include physical punishment into the scope of abuse, and promoting zero tolerance of violence.

The media's mass publicity and image construction are driving the public's awareness of child abuse in the right direction, towards greater recognition of child abuse, and have become an indispensable supervision tool in child protection practices. However, there are also inevitably some issues that need to be considered and addressed. Many news or discussions were always reported from the perspective of adults, but they neglected child's voice and the protection of child's privacy. The cases of child abuse were discussed by a third person, and the abused child's own opinions and expressions were subordinated to adults' values and media's needs. This directly resulted in a disproportionate report of children views and children being underrepresented. Nanjing Child Abuse Case is a typical example. The foster son repeatedly expressed missing his foster mother and hoping to get his foster mother back. But the voice was drowned out by the public's condemnation against his foster mother and call for the applicant functions to exert severe punishment on her and deprive her of the adoptive relationship. A child's voice was once again ignored by the public. Therefore, the media should pay more attention to these problems and better perform their duties.

\section{References}

[1] Amy Chua, Battle Hymn of the Tiger Mother (Penguin Group Inc. USA 2011).

[2] D.P. QIAO. Conceptualizing Child Abuse in China (Social Sciences of Academic Press, China 2012).

[3] Information on http://news.xinhuanet.com/edu/2013-04/20/c_124605805.htm.

[4] Information on http://news.sina.com.cn/s/2012-12-01/094025706467.shtml

[5] Information on http://blog.sina.com.cn/s/blog_95869b060101kdfu.html.

[6] Information on http://news.sina.com.cn/s/wh/2015-09-30/doc-ifxieymv7755842.shtml. 
[7] Information on http://news.sina.com.cn/s/2012-10-26/023925440842.shtml.

[8] Information on http://news.xinhuanet.com/photo/2013-05/12/c_124698509.htm.

[9] Information on http://news.xinhuanet.com/legal/2015-03/03/c_1114506118.htm\#pinglun.

[10] Information on http://www.sd.xinhuanet.com/sdws/2014-04/16/c_1110271955.htm.

[11] Information on http://gd.sina.com.cn/news/s/2013-11-13/073453903.html.

[12] Information on http://news.sina.com.cn/s/2014-10-22/151431028543.shtml.

[13] Information on http://video.sina.com.cn/p/news/o/doc/2017-04-22/205266091103.html. 